\title{
Productive teacher job satisfaction: Disentangling organizational climate, facility management, and organizational citizenship behavior
}

\author{
Soparidah, R. Madhakomala, Ivan Hanafi
}

Postgraduate Study Management of Education, Universitas Negeri Jakarta, Indonesia

\begin{tabular}{l}
\hline \hline Article Info \\
\hline Article history: \\
Received Dec 15, 2020 \\
Revised Aug 7, 2021 \\
Accepted Sep 10, 2021
\end{tabular}

\section{Keywords:}

Citizenship behavior Infrastructure management Job satisfaction Organizational climate Productive teachers

\begin{abstract}
Productive teachers are teachers who teach vocational subjects. A productive teacher has complex characteristics and professional requirements so that job satisfaction must be considered. The research objective was to analyze the direct effect of organizational climate, management of facilities and infrastructure, organizational citizenship behavior on the job satisfaction of productive teachers. The research employed a quantitative approach with a survey method. The research sample was conducted at 46 private vocational high schools with a total of 270 productive teachers in East Jakarta, Indonesia. Data was analyze using path analysis. The results showed that there is no direct influence of organizational climate on job satisfaction of productive teachers; there is no direct effect of facility and infrastructure management on job satisfaction of productive teachers; there is a direct influence of organizational citizenship behavior on job satisfaction of productive teachers.
\end{abstract}

This is an open access article under the CC BY-SA license.

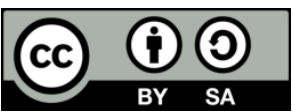

\section{Corresponding Author:}

Soparidah

Postgraduate Study Management of Education

Universitas Negeri Jakarta

Kota Jakarta Timur, Daerah Khusus Ibukota Jakarta, Indonesia

Email: soparidahjasmine.02@gmail.com

\section{INTRODUCTION}

Vocational high school (VHS) is a formal education institution that prepares graduates who are following the needs of the industrial world and are expected to be entrepreneurs [1]. However, until now, the link and match between VHS graduates and the industrial world still need to be improved [2]. The quality and quantity of teachers, especially productive teachers, is one of the causes of imperfect links and matches and the quality of learning in VHS [3]. The shortage of quality teachers, especially productive teachers in VHS reaching 91,681 teachers adds to the complexity of the problem of the quality of education in VHS [4].

One of the factors causing the low number of productive teachers in VHS is low teacher job satisfaction [4]. Teachers in VHS who need to pay attention to job satisfaction are productive teachers. Vocational teachers in productive programs have specific professional characteristics and requirements (competencies), namely: i) Have adequate practical skills in all productive fields of study (subjects); ii) Able to organize learning (education and training) that is relevant to the competencies needed by the world of work; iii) Able to design learning (education and training) in schools and the business or industrial world [5]. A productive teacher has complex characteristics and professional requirements including having adequate practical skills in all fields of study (productive subjects), being able to organize learning (education and training) relevant to the competencies needed by the world of work, and being able to design learning in 
schools and the business or industrial world [3]. So, it can be said to be a productive teacher requires high skills and great responsibility.

Low teacher job satisfaction results in high absenteeism, low discipline, and high turnover [6]. In contrast, teachers who express high satisfaction in their work tend to be more productive, have high involvement, and are less likely to resign compared to employees who feel less satisfied. Based on this, it can be concluded that productive teacher job satisfaction is one of the important factors in creating quality education, productive teachers become the steering core for VHS in all skill competencies. Various factors affect teacher job satisfaction, including organizational climate, management of facilities and infrastructure, and organizational citizenship behavior [7], [8].

Organizational climate is more to the atmosphere felt by organizational members, both physical and non-physical towards the organization [9]. Teachers who have worked in schools will of course have perceptions or feelings as a result of the teacher's interactions with their environment. The feeling of comfort or discomfort can be one of the perceptions felt by the teacher. This results in an organizational climate that can make teachers satisfied in their work in carrying out their duties at school [10].

Without a sense of a well-created organizational climate, there is a concern that unhealthy organizational conditions may arise [11]. Where the working teachers will lose their enthusiasm to work. It is feared that it will make teachers not stay in school for long. These conditions can result in a high number of teachers who are dissatisfied with their work. So that every school tries to always create a conducive organizational climate. There has been evidence that the influence of climate is weak, for example on organizational citizenship behavior (OCB) resulting in weak results as well. Conversely, if the strength (climate) is seen to affect the effect (result). More specifically, organizational climate is a relatively durable quality that teachers experience, influence their behavior, and are based on their collective perceptions [12]. So that the organizational climate is thought to be one of the predictors in creating job satisfaction. Organizational climate has a significant effect on job satisfaction because a conducive organizational climate can provide comfort to all citizens in the organization including teachers, thereby improving the performance of all employees and making it easier to achieve organization goals.

Management of facilities and infrastructure also has an important role in creating job satisfaction for productive teachers. Satisfaction depends on the match between working conditions [12]. The working conditions in question are partly caused by the management of facilities and infrastructure in the workplace. The facility of management is a profession that encompasses multiple disciplines to ensure the functionality of the built environment by integrating people, place, process, and technology [13]. To ensure that the facilities and infrastructure in schools are following the needs of students, it is necessary to carry out good management, so we need a person in charge of facilities and infrastructure that is professional and integrated.

To provide quality services, schools need to prepare adequate management of school facilities and infrastructure to support the learning process and make productive teachers satisfied at work [14]. Good management of facilities and infrastructure has a positive influence on the school climate in a comprehensive manner so that the components in schools can optimize the use of facilities and infrastructure as needed. For this reason, it is necessary to plan, organize, mobilize, and monitor continuously the management and use of facilities and infrastructure owned by the school so that it creates a sense of satisfaction at work [15].

Parents in school selection are influenced by the facilities provided by the school [16]. However, it is not easy for a school principal to manage school facilities and infrastructure that are well integrated. Because effective management of facilities and infrastructure requires certain knowledge. the effectiveness of maintaining facilities and infrastructure requires knowledge to list needs, the age of use of the equipment and the impact of the equipment needed on supporting school activities [17].

Good management of facilities and infrastructure can improve student achievement and satisfaction of productive teachers at work [18]. So, it is important to manage facilities and infrastructure effectively to create a good quality of learning and job satisfaction for teachers, especially productive teachers. Various works of literature underline the importance of physical facilities and management of facilities and infrastructure in creating productive teacher job satisfaction and organizational citizenship behavior [19]. Teachers who work well and wholeheartedly indicate that the teacher has a sense of belonging to the school or is called a sense of belonging in the organization. Teachers who have high OCB will be willing to attend the office early, come home late, are willing to do tasks that are not their responsibility, and always maintain the sustainability of the organization. Meanwhile, employees who have low OCB will have the opposite attitude [20].

Schools need high OCB from each teacher to produce satisfaction and good performance. High OCB will result in schools being able to move more optimally and effectively. It is easier to achieve the welfare of school members and teachers. A qualified teacher understands that motivating students is important in increasing learning achievement [21]. The level of job satisfaction of teachers in schools will also be high because teachers feel more part of the extended family at school. So that the goals of education 
in learning can be achieved according to the target. Problems that arise regarding the low job satisfaction of productive teachers. This finding is reinforced by the results of simple observations when communicating with productive teachers of VHS in East Jakarta. Complaints that were submitted ranged from the unsupportive working climate, often given additional assignments from the principal, naughty students to inadequate facilities. This is a natural thing because private schools are not fully supported by the government, especially in terms of providing facilities and infrastructure.

The low job satisfaction of productive teachers is thought to be caused by organizational climate, management of facilities and infrastructure, and organizational citizenship behavior. This is because until now there has been no empirical research on productive teacher job satisfaction seen from the aspects of organizational climate, management of facilities and infrastructure, and OCB. The learning process in schools becomes effective if the quality of the teaching teacher and a comfortable work environment supports the teacher at work. One of the qualified teachers has a high OCB, while the work environment is one of the indicators is the management of facilities and infrastructure and a conducive organizational climate [22]. If this is fulfilled, student learning achievement can be achieved following national education standards. The purpose of this research is to analyze the direct influence of organizational climate on job satisfaction, the direct influence of management facilities and infrastructure on job satisfaction, and the direct effect of OCB on job satisfaction.

\section{RESEARCH METHOD}

The study employed a quantitative approach with a survey method. The results of the survey method with this causal approach were analyzed using path analysis. The endogenous variable group is teacher job satisfaction while the exogenous variable group is the organizational climate, facility and infrastructure management, OCB. The population in this study was productive teachers from 46 VHS scattered in East Jakarta, Indonesia. Not all teachers in VHS are productive teachers. Productive teachers are teachers who teach vocational subjects in VHS. Productive teachers teach one particular skill from a variety of skills taught in VHS. For example, vocational high schools majoring in automotive have productive teachers in retreading tires, engines and vehicle frames. The sampling technique used purposive sampling because this determination technique in determining the sample of the productive teacher representatives from each VHS was considered [23]. To find out a large number of representative samples as the validity of the generalization process for this study, a sampling technique was used using the Slovin formula [24]. The sample size is 46 schools and each school has an average of five to six productive teachers, so the total sample is 270 teachers.

Collecting data using a questionnaire which is arranged based on the indicators of each variable. productive teacher job satisfaction variables have indicators: the job itself, superiors, coworkers, promotion and salary received. The organizational climate variable has indicators: physical environment, social environment, and physical condition of organizational members. The facility and infrastructure management variables have indicators: planning, inventory, procurement, maintenance, and supervision. OCB has several variables: sportsmanship, altruism, courtesy, civic virtue, conscientiousness. The process of calculating data analysis using SPSS 24 software. The research hypothesis is:

H1: Organizational climate has a direct influence on the job satisfaction of productive teachers

$\mathrm{H} 2$ : Management of facilities and infrastructure has a direct influence on job satisfaction of the productive teacher

H3: Organizational citizenship behavior has a direct influence on the job satisfaction of productive teachers

\section{RESULTS AND DISCUSSION}

Data were analyzed using SPSS 24 software with output table Summary Model, Anova, and Coefficients. Table 1 provides the results of calculating the partial variable test conditions, while Table 2 presents the results of calculating the F value using SPSS 24 in partial variable testing. Based on Table 1, it is obtained that the value of $\mathrm{R}$ square $=0.453$. Table 2 reveals that Anova test obtained an $\mathrm{F}$ value of 73.508 with a probability value $(\mathrm{sig})=0.000$, then the sig. value $<0.05$, the decision Ho is rejected and Ha is accepted. Therefore, partial testing between variables can be done. Table 3 presents the results of data calculations using SPSS 24 in the form of partial correlation coefficients and the significance of the relationship of each variable. 
Table 1. Model summary

\begin{tabular}{cccccccccc}
\hline \multirow{2}{*}{ Model } & R & \multirow{2}{*}{ R Square } & $\begin{array}{c}\text { Adjusted } \\
\text { R Square }\end{array}$ & $\begin{array}{c}\text { Std. Error of } \\
\text { the estimate }\end{array}$ & R Square change & F change & df1 & df2 & Sig. F change \\
\hline 1 & $0.673^{\mathrm{a}}$ & 0.453 & 0.447 & 7.497 & 0.453 & 73.508 & 3 & 266 & 0.000 \\
\hline
\end{tabular}

a. Predictors: (Constant), organizational citizenship behavior, management of facilities and infrastructure, organizational climate

b. Dependent variable: Job satisfaction

Table 2. Anova test result

\begin{tabular}{ccccccc}
\hline & Model & Sum of Squares & df & Mean Square & F & Sig. \\
\hline 1 & Regression & 12394.767 & 3 & 4131.589 & 73.508 & $0.000^{\mathrm{b}}$ \\
& Residual & 14950.774 & 266 & 56.206 & & \\
& Total & 27345.541 & 269 & & & \\
\hline
\end{tabular}

a. Dependent Variable: job satisfaction

b. Predictors: (Constant), organizational citizenship behavior, management of facilities and infrastructure, organizational climate

Table 3. Coefficients

\begin{tabular}{|c|c|c|c|c|c|c|}
\hline \multirow{2}{*}{\multicolumn{2}{|c|}{ Model }} & \multicolumn{2}{|c|}{ Unstandardized coefficients } & \multirow{2}{*}{$\begin{array}{c}\text { Standardized coefficients } \\
\text { Beta }\end{array}$} & \multirow[b]{2}{*}{$t$} & \multirow{2}{*}{ Sig. } \\
\hline & & $\mathrm{B}$ & Std. Error & & & \\
\hline \multirow[t]{4}{*}{1} & (Constant) & 32.888 & 4.283 & & 7.679 & 0.000 \\
\hline & Organizational climate & 0.043 & 0.055 & 0.044 & 0.783 & 0.434 \\
\hline & Management of facilities and infrastructure & 0.049 & 0.039 & 0.063 & 1.269 & 0.205 \\
\hline & Organizational citizenship behavior & 0.582 & 0.055 & 0.619 & 10.617 & 0.000 \\
\hline
\end{tabular}

a. Dependent variable: Job satisfaction

\subsection{H1: Organizational climate has a direct influence on the job satisfaction of productive teachers}

The path analysis significance test was analyzed by comparing the sig. value and probability value of 0.05 . The test criterion if the probability value is $0.05 \leq \mathrm{sig}$. value, then Ho is accepted and Ha is rejected, which means not significant. Meanwhile, if the probability value is $0.05 \geq \operatorname{sig}$. value, then Ha is accepted and Ho is rejected, which means significant. Table 3 contains the path coefficient value, there is a sig. value of 0.434 which means it is greater than the probability value of 0.05 or a value of $0.05<0.434$, then Ho is accepted and $\mathrm{Ha}$ is rejected. Organizational climate does not have a direct influence on job satisfaction. This finding is contrary to the hypothesis formulated by the researchers. An individual's expression of personal wellbeing is associated with doing the job assigned [25]. Job satisfaction is a level of positive or negative feelings about several aspects of work, work situations, and relationships with colleagues [26].

These positive or negative feelings arise after employees interact with the work they are doing. Another opinion says the level of job satisfaction depends on the level of feeling intrinsically and extrinsically received by the individual. The intrinsic and extrinsic results that each person receives is different [25]. There are two factors that influence job satisfaction, namely factors that come from within the employee (intelligence quotient (IQ) level, special skills, biographical characteristics, education, and work experience); and occupational factors (type of work, organizational structure, rank, position, quality of supervision, financial security, promotion opportunities, social interactions, and work relationships). According to this opinion, physical conditions and social interactions are some of the components that affect job satisfaction which is part of the indicators of organizational climate.

The organizational climate affects job satisfaction in each country, because the organizational climate is formed based on individual teacher perceptions and becomes the starting point for exploring the organizational climate [27]. The difference between the results of the study and the hypotheses formulated can be explained by the results of research which state that the dominant factors affecting teacher job satisfaction are the work itself and the leadership of the school principal [28]. The leadership of the principal greatly influences the organizational climate that is formed in the school because it will determine the social interactions that arise in the school. The leadership factor is also an indicator that dominates the formation of an organizational climate in various sectors [29]. This assumption is reinforced by another research that states that the dominant factor in creating teacher job satisfaction is the social environment that appears in schools in the absence of seniority among teachers.

The other studies show evidence that the factors that determine the formation of organizational climate in schools are gender and unity [29]. It can be assumed that the weak and insignificant organizational climate in influencing teacher job satisfaction is due to the leadership of the principal of private vocational schools in East Jakarta which results in a less conducive atmosphere of social interaction at school. So, the majority of teachers at private vocational schools in East Jakarta have a fairly high job satisfaction but not with the organizational climate felt by teachers in schools. 


\subsection{H2: Management of facilities and infrastructure has a direct influence on job satisfaction of the productive teacher}

The path analysis significance test was analyzed by comparing the probability value of 0.05 and the sig. value. The test criterion if the probability value is $0.05 \leq$ sig. value, then Ho is accepted and Ha is rejected which means not significant. Meanwhile, if the probability value is $0.05 \geq$ sig. value, then Ha is accepted and Ho is rejected, which means significant. It can be seen that the sig. column in Table 3 has a sig. value 0.205 , which means that the sig. value is greater than the probability value 0.05 or the value $0.05<0.205$, then $\mathrm{Ho}$ is accepted and $\mathrm{Ha}$ is rejected. This means that the path analysis coefficient is not significant. So, the management of facilities and infrastructure is not significant for teacher job satisfaction.

This finding is contrary to the hypothesis formulated by the researchers. If we look back at the grand theory, job satisfaction depends on the match between working conditions. The working conditions in question are partly caused by the management of facilities and infrastructure in the workplace. Management of facilities and infrastructure is an activity used by various scientific disciplines to ensure that all supporting facilities are in place, according to function and can be used by integrating people, places, processes, and technology. Facilities and infrastructure management is a profession that harmonizes a variety of tools to ensure that all of them function properly in building an environment consisting of people, places, processes, and technology. So it can be said that good management of facilities and infrastructure can be a determining factor in creating a work environment to support whether employees are satisfied or not [30]. If the facilities and infrastructure are not properly managed, it will cause bad value for employees. This means affecting the extrinsic level of the teacher while in school. These factors can affect teacher job satisfaction.

The difference between the results of the research and the hypotheses formulated can be explained by the previous studies [31], [32] which state that it is important for a teacher to know the working conditions that are formed in school as one of the consequences of managing facilities and infrastructure. Part of the management of the most important facilities and infrastructure management and directly in contact with the teacher is the part of organizing (providing) facilities and infrastructure. If the facilities and infrastructure owned by the school are complete and following the designation, it can make it easier for teachers to work. Conversely, if it is incomplete and out of date, it will make it difficult for teachers to work [33].

The evaluation of facilities and infrastructure in VHS affects the quality of education, learning outcomes, and teacher satisfaction in teaching. Therefore, it is necessary to revise policies in the provision of infrastructure as has been done by developed countries [34]. Management of facilities and infrastructure will create good or bad working conditions that will affect teacher job satisfaction. If not done, in addition to increasing dissatisfaction at work it can also cause burnout [35]. So, it can be assumed if the weak and insignificant management of facilities and infrastructure in affecting teacher job satisfaction is due to the availability of facilities and infrastructure for private vocational schools in East Jakarta which still have to be improved, resulting in less than optimal teaching. The majority of teachers in private vocational schools in East Jakarta have high job satisfaction but are not followed by maximum management of facilities and infrastructure in schools.

\subsection{H3: Organizational citizenship behavior has a direct influence on the job satisfaction of productive teachers}

The path analysis significance test was analyzed by comparing the probability value of 0.05 and the sig. value. The test criterion if the probability value is $0.05 \leq$ sig. value, then Ho is accepted and Ha is rejected which means not significant. Meanwhile, if the probability value is $0.05 \geq \operatorname{sig}$. value, then $\mathrm{Ha}$ is accepted and Ho is rejected, which means significant. It can be seen in Table 3 that the sig. value is 0.000 , which is smaller than the probability value of 0.05 or the value of $0.05>0.000$, then Ho is rejected and $\mathrm{Ha}$ is accepted. This means that the path analysis coefficient is significant. It means that OCB has a direct influence on the job satisfaction of productive teachers.

The results of these studies are by the research hypothesis formulated. The organ also identifies that employee work behavior OCB is related to job satisfaction [36]. Other results show that the dominant indicator in creating teacher job satisfaction which is influenced by OCB is altruism, which means personal choice behavior to help others solve organizational problems where the teacher takes shelter [37]. This means that teachers are willing to help colleagues at school even though they are not answered and or outside work hours. This finding is also reinforced by the results of previous study [38], which states that the main characteristic of teachers who have OCB is the employee's altruism.

OCB is influenced by six factors, there are a positive work attitude, cynicism, workplace values, job characteristics, job title, and length of work. The first factor is a positive work attitude. Positive work attitudes can be in the form of low absenteeism and employee turnover rates in the organization [39]. This positive work attitude is owned by employees because employees are satisfied with their work. Other factors can be in the form of organizational support, trust, and the work quality of employees. Job satisfaction that 
can be obtained in a work environment is a sense of pride, satisfaction with the success of carrying out tasks to completion. Job satisfaction causes employees to want to cooperate and contribute to the organization. Employees who are satisfied with work will give replies to the organization in the form of attachment and behave as good organizational members, this is known as OCB.

\section{CONCLUSION}

Based on the results and discussion that have been described, this study concluded that: first, there is no direct influence of organizational climate has a direct influence on the job satisfaction of productive teachers. This result may be due to the ineffective leadership applied in vocational high schools in East Jakarta, which makes the organizational climate felt by teachers not conducive. Because some of the results of previous studies concluded that leadership is a dominant factor in creating organizational climate. Second, there is no direct and significant effect of management of facilities and infrastructure on productive teacher job satisfaction. This result may be due to the weak and insignificant direct influence of the management of facilities and infrastructure in affecting teacher job satisfaction due to the availability of facilities and infrastructure for private vocational schools in East Jakarta which still need to be improved. This condition implies in teaching process become less optimal. Third, there is a direct and significant effect of organizational citizenship behavior on teacher job satisfaction.

There is a need to improve the quality of school principal leadership and organizational citizenship behavior. It can be done by creating a culture to always support among teachers. This study has limitation in term of the sample. It is only taken from private vocational high school (VHS) in Jakarta. Further research is required in a wider area with bigger sample size.

\section{REFERENCES}

[1] H. Prasetyono, A. Abdillah, T. Djuhartono, I. P. Ramdayana, and L. Desnaranti, "Improvement of teacher's professional competency in strengthening learning methods to maximize curriculum implementation," International Journal of Evaluation and Research in Education (IJERE), vol. 10, no. 2, pp. 720-727, 2021, doi: 10.11591/ijere.v10i2.21010.

[2] H. Prasetyono, A. Abdillah, and D. Fitria, "Academic supervision toward teacher's performance through motivation as intervening variable," Journal of Education and Learning (EduLearn), vol. 12, no. 2, pp. 188-197, 2018, doi: 10.11591/edulearn.v12i2.7324.

[3] T. Wiyanto, M. Samani, and Sugiyono, "The developing teaching practice model as an effort to improve the quality of mechanical engineering vocational school teachers," J. Pendidik. Vokasi, vol. 7, no. 3, pp. 349-363, 2017, doi: 10.21831/jpv.v7i3.17923.

[4] A. G. Tamrin, S. PH, and Soenarto, "The link and match of the demand and supply for productive vocational school teachers with regard to spectrum of vocational skills in the perspective of education decentralization," $J$. Pendidik. Vokasi, vol. 8, no. 1, pp. 40-52, 2018, doi: 10.21831/jpv.v8i1.15135.

[5] T. Kasman, Productive Teacher Development Policy Patterns based on Presidential Instruction Number 9, 2016. (in Indonesia). Jakarta: Direktorat Pembinaan Sekolah Menengah Kejuruan, Direktorat Jenderal Pendidikan Dasar dan Menengah Kementerian Pendidikan dan Kebudayaan RI, 2017.

[6] C. S. Lee, Y. C. Chen, P. L. Tsui, and T. H. Yu, "examining the relations between open innovation climate and job satisfaction with a PLS path model," Quality \& Quantity, vol. 48, no. 3, pp. 1705-1722, 2014, doi: 10.1007/s11135-013-9869-6.

[7] C. C. Huang, C. S. You, and M. T. Tsai, "A multidimensional analysis of ethical climate, job satisfaction, organizational commitment, and organizational citizenship behaviors," Nurs. Ethics, vol. 19, no. 4, pp. 513-529, 2012, doi: 10.1177/0969733011433923.

[8] L. Zhang, Y. Qiu, and E. Teng, "Cross-level relationships between justice climate and organizational citizenship behavior: Perceived organizational support as mediator," Soc. Behav. Pers., vol. 45, no. 3, pp. 387-397, 2017.

[9] J. G. N. Salazar, G. J. B. Cosiun, and D. R. Torres, "Relationship of the organizational climate with the job satisfaction in a company of the construction sector," Rev. Científica ECOCIENCIA, vol. 6, no. 1, pp. 1-25, 2019.

[10] C. Zehir, B. Müceldili, E. Altindağ, Y. Şehitoğlu, and S. Zehir, "Charismatic leadership and organizational citizenship behavior: The mediating role of ethical climate," Soc. Behav. Pers., vol. 42, no. 8, pp. 1365-1376, 2014, doi: 10.2224/sbp.2014.42.8.1365.

[11] E. Hur, L. Jeon, and C. K. Buettner, "Preschool Teachers' Child-Centered Beliefs: Direct and Indirect Associations with Work Climate and Job-Related Wellbeing," Child Youth Care Forum, vol. 45, no. 3, pp. 451-465, 2016.

[12] D. Hellriegel and J. W. Slocum, Organizational behavior, 13th ed. Mason: South-Western, 2008.

[13] D. G. Cotts, K. O. Roper, and R. P. Payant, The facility management handbook, 3th ed. New York: American Management Association, 2010.

[14] S. Akhtar, "Status of Infra-Structure, Facilities and Level of Achievements of the Students at Secondary Schools Level," Pakistan J. Soc. Sci., vol. 35, no. 2, pp. 745-762, 2015.

[15] P. Barrett and D. Baldry, Facilities management towards best practice, 2nd ed. Malden: Blackwell Science Ltd, 2004. 
[16] R. Basak and A. Ghosh, "School environment and locus of control in relation to job satisfaction among school teachers - A study from Indian perspective," Procedia - Social and Behavioral Sciences, vol. 29, pp. 1199-1208, 2011.

[17] M. U. Kottwitz, R. Schnyder, M. Berset, and A. Elfering, "Thirst at Work Implies More Than Just Inadequate Facilities for Breaks," Appl. Psychophysiol. Biofeedback, vol. 42, no. 3, pp. 223-234, 2017.

[18] H. Gani and H. Usman, "Developing a model of partnership management between the vocational high school and the employment domain in the curriculum of industrial working practice," J. Pendidik. Vokasi, vol. 8, no. 3, pp. 289-299, 2018.

[19] A. Khalid, Z. Javed, M. Nasir, and S. Afreen, "The role of public private partnership in provision of physical facilities in schools: A sociological study of District Bhakkar," Bull. Educ. Res., vol. 38, no. 1, pp. 225-234, 2016.

[20] S. Altuntas and U. Baykal, "Relationship between nurses' organizational trust levels and their organizational citizenship behaviors," J. Nurs. Scholarsh., vol. 42, no. 2, pp. 186-194, 2010.

[21] H. Prasetyono, A. Abdillah, T. Anita, A. Nurfarkhana, and A. Sefudin, "Identification of the decline in learning outcomes in statistics courses using the Chi-squared automatic interaction detection method," J. Phys. Conf. Ser., vol. 1490, pp. 1-9, 2020.

[22] B. Nepal, "Relationship among school's infrastructure facilities, learning environment and student's outcome," Int. J. Res. Soc. Sci. Humanit., vol. 2, no. 5, pp. 44-57, 2016.

[23] D. Fitria, A. Abdillah, H. Prasetyono, and I. D. Cahyo, "The Difference of Enterprises Taxpayers Compliance after Tax Amnesty," J. Econ. Policy, vol. 12, no. 1, pp. 86-99, 2019.

[24] H. Prasetyono, A. Abdillah, T. Widiarto, and H. Sriyono, "Character-based economic learning implementation and teacher's reinforcement on student's affective competence in minimizing hoax," Cakrawala Pendidik., vol. 37, no. 3, pp. 426-435, 2018.

[25] J. L. Gibson, J. M. Ivancevich, J. H. Donnelly, and R. Konopaske, Organizations: Behavior, Structure, Processes. Boston: McGraw-Hill 2009.

[26] Y. F. Zakariya, K. Bjørkestøl, and H. K. Nilsen, "Teacher job satisfaction across 38 countries and economies: An alignment optimization approach to a cross-cultural mean comparison," Int. J. Educ. Res., vol. 101, 2020, doi: 10.1016/j.ijer.2020.101573.

[27] P. Naiyananont and T. Smuthranond, "Relationships between ethical climate, political behavior, ethical leadership, and job satisfaction of operational officers in a wholesale company, Bangkok Metropolitan region," Kasetsart J. Soc. Sci., vol. 38, no. 3, pp. 345-351, 2017.

[28] A.-S. Israel and V. L. Hendrix, "Organizational climate and teachers' job satisfaction in a multi-cultural milieu: The case of the Bedouin Arab Schools in Israel," Int. J. Educ. Dev., vol. 15, no. 2, pp. 141-153, 1995.

[29] G. Ceyda and P. Sevinc, "Determination of high schools organizational climate," in Procedia - Social and Behavioral Sciences, vol. 46, pp. 2947-2950, 2012, doi: 10.1016/j.sbspro.2012.05.595.

[30] E. T. Bekru, A. Cherie, and A. A. Anjulo, "Job satisfaction and determinant factors among midwives working at health facilities in Addis Ababa city, Ethiopia," Plos One J., vol. 12, no. 2, pp. 1-17, 2017.

[31] M. Adib-Hajbaghery and Z. Kamrava, "Iranian teachers' knowledge about first aid in the school environment," Chinese J. Traumatol. - English Ed., vol. 22, no. 4, pp. 240-245, 2019.

[32] C. Foley and M. Murphy, "Burnout in Irish teachers: Investigating the role of individual differences, work environment and coping factors," Teach. Teach. Educ., vol. 50, pp. 46-55, 2015.

[33] A. Smantser and E. Ignatovitch, "Future Teacher Training for Work in Inclusive Educational Environment: Experimental Study Results," Procedia - Soc. Behav. Sci., vol. 214, pp. 422-429, 2015.

[34] C. K. Tanner, "Revision of Policy on Planning School Infrastructure in the United States," J. Int. Soc. Educ. Plan., vol. 19, no. 1, pp. 37-44, 2010.

[35] M. Claro, et al., "Teaching in a Digital Environment (TIDE): Defining and measuring teachers' capacity to develop students' digital information and communication skills," Comput. Educ., vol. 10, pp. 1-18, 2018.

[36] N. T. Feather and K. A. Rauter, "Organizational Citizenship Behaviours in Relation to Job Status, Job Insecurity, Organizational Commitment and Identification, Job Satisfaction and Work Values," J. Occup. Organ. Psychol., vol. 77, pp. 81-94, 2004.

[37] S. Belwalkar, V. Vohra, and A. Pandey, "The relationship between workplace spirituality, job satisfaction and organizational citizenship behaviors: An empirical study," Soc. Responsib. J., vol. 14, no. 2, pp. 410-430, 2018.

[38] N. Athirah, et al., "The Moderating Role of Organizational Citizenship Behavior on The Relationship between Organizational," International Journal of Arts \& Sciences, vol. 11, no. 01, pp. 467-478, 2018.

[39] A. Akturan and H. G. Cekmecelioğlu, "The Effects of Knowledge Sharing and Organizational Citizenship Behaviors on Creative Behaviors in Educational Institutions," Procedia - Social and Behavioral Sciences, vol. 235, pp. 342-350, 2016, doi: 10.1016/j.sbspro.2016.11.042. 